\title{
Selection of Excavating Equipment for the Outpacing Development of the Coal-bearing Zone
}

\author{
Alexander Katsubin ${ }^{1, *}$, Sergey Markov², Alexey Khoreshok ${ }^{2}$, and Maxim Tyulenev ${ }^{2}$ \\ ${ }^{1}$ JSC “SUEK-Kuzbass", Surface Mining Office, 652507 Leninsk-Kuznetsky, 1 Vasil'eva st., Russian \\ Federation \\ ${ }^{2}$ T.F. Gorbachev Kuzbass State Technical University, Mining Institute, 650000 Kemerovo, 28 \\ Vesennyaya st., Russian Federation
}

\begin{abstract}
When choosing equipment for working out a coal-bearing zone of a quarry field, one of the most important factors is the use of excavator equipment available at the enterprise. From previously published works, the main advantages and disadvantages of the most common types of excavators (rope shovel and backhoe) are known. In this article, the authors propose an organizational scheme for the development of a coal-bearing zone using both types of excavators. A technological scheme of the development of a coal-bearing and a coalless zone of a quarry field by the complexes of these excavators is given. The advantages of the given scheme of mining are determined.
\end{abstract}

\section{Introduction}

At formation of excavation and loading complexes and creating of technological schemes of mining operations in coal-bearing zones of open pits it is necessary to consider conditions of occurrence of coal seams and a set of the serially made mining equipment. Technological schemes of mining operations based on the use of mining and loading complexes, should meet the following conditions.

Requirements to the elements of excavation and loading complexes: the ability to work in the same climatic conditions; comparability of performance of separate elements of the complex; mobility of elements of the complex; possibility to work out the coal-and-rock massif at one method of preparation of rocks for excavation; use of mainly the same type of energy; possibility of spatial manipulation of the working body of the machines of the complex [1-12].

Requirements for construction of technological schemes with the use of excavation and loading complexes:

- elimination of mutual hindrances in joint operation of the complex elements;

- ensuring completeness and quality of coal seams extraction;

- maximum use of working parameters of the elements of the excavation and loading complex;

*Corresponding author: katsubin_suek@mail.ru 
- minimization of shunting non-productive operations of the complex elements;

- creating conditions for the movement of vehicles mainly on the unblasted rock massif;

- possibility of visual mutual review of the complex elements;

- ensuring the safety of the work of the elements of the excavation and loading complex.

The basis for the formation of excavation and loading complexes for the development of coal-bearing zones of the quarry fields is a serial mining equipment for opencast mining operations.

\section{Methods}

In the practice of Kuzbass open pits for the mining of coal formations two systems of mining according to V.V. Rzhevsky classification $[13,14]$ mainly use: a longitudinal single or double-sided deepening system. Let's consider preconditions to formation of requirements of technology of extraction of a rock mass from a position of formation of structure of an excavation complex (Table 1).

Table 1. Characteristics of the mining system from the point of view of formation of development requirements by the excavation complex.

\begin{tabular}{|c|c|}
\hline Parameter name & Detailed specification description \\
\hline maximum coal extraction from subsoil & $\begin{array}{l}\text { some of the coal reserves are not worked out, } \\
\text { because of the cutting trench link to the } \\
\text { powerful seam of the formation and the } \\
\text { movement of the mining front from the hanging } \\
\text { side of the deposit to the lying one }\end{array}$ \\
\hline $\begin{array}{c}\text { provision of optimal conditions for separate } \\
\text { mining of coal seams by existing and } \\
\text { prospective equipment }\end{array}$ & $\begin{array}{l}\text { coal is first extracted by longitudinal motion of } \\
\text { the front, then overburden, which ensures } \\
\text { separate mining }\end{array}$ \\
\hline $\begin{array}{l}\text { minimizing the potential for coal dilution } \\
\text { by bedrocks }\end{array}$ & $\begin{array}{l}\text { depends on excavation equipment at stripping } \\
\text { and mining operations, clogging reaches 10- } \\
15 \% \text { due to the use of rope shovels and } \\
\text { decreases with the use of hydraulic shovels and } \\
\text { backhoes }\end{array}$ \\
\hline $\begin{array}{l}\text { ensuring the stability of the quality of } \\
\text { mined coal }\end{array}$ & $\begin{array}{l}\text { the condition is provided by the technical } \\
\text { complex for handling, sorting and processing }\end{array}$ \\
\hline $\begin{array}{l}\text { capacity of excavators during mining of } \\
\text { coal-bearing zones }\end{array}$ & $\begin{array}{l}\text { capacity is ensured by the excavator moving } \\
\text { along the long axis of the quarry field }\end{array}$ \\
\hline $\begin{array}{l}\text { creation of conditions for free maneuvering } \\
\text { of excavation and transport equipment in } \\
\text { the face zone }\end{array}$ & $\begin{array}{l}\text { Difficulties associated with the peculiarities of } \\
\text { the longitudinal mining front: simultaneous } \\
\text { deepening of the thickest seam of the formation } \\
\text { and stripping of the sides on the overlying } \\
\text { benches }\end{array}$ \\
\hline separate extraction of rock and coal layers & $\begin{array}{l}\text { clogging and losses depend on the existing } \\
\text { mining equipment fleet }\end{array}$ \\
\hline $\begin{array}{l}\text { ensuring that all components of the face are } \\
\text { handled separately }\end{array}$ & $\begin{array}{l}\text { components are handled alternately - } \\
\text { longitudinal mining front }\end{array}$ \\
\hline $\begin{array}{c}\text { coal mining of the same grade composition } \\
\text { during the day }\end{array}$ & one brand of coal - one coal seam is mined \\
\hline
\end{tabular}




\section{Results}

Taking into account the above mentioned advantages and disadvantages it is proposed to use the advantages of each type of mining complex. The principal organizational scheme of rock mass development is as follows (Fig. 1).

In case of transport technology, excavation of the coal-and-rock massif is performed by horizontal layers: after one layer within the block is removed, deepening and mining of the underlying layer takes place. For the coal-bearing zone, alternating the advantages of each excavator (rope shovel and backhoe) in accordance with the principle set out in Fig. 1, the coal-bearing zone is worked out, and outside the coal-bearing zone only rope shovels are used.

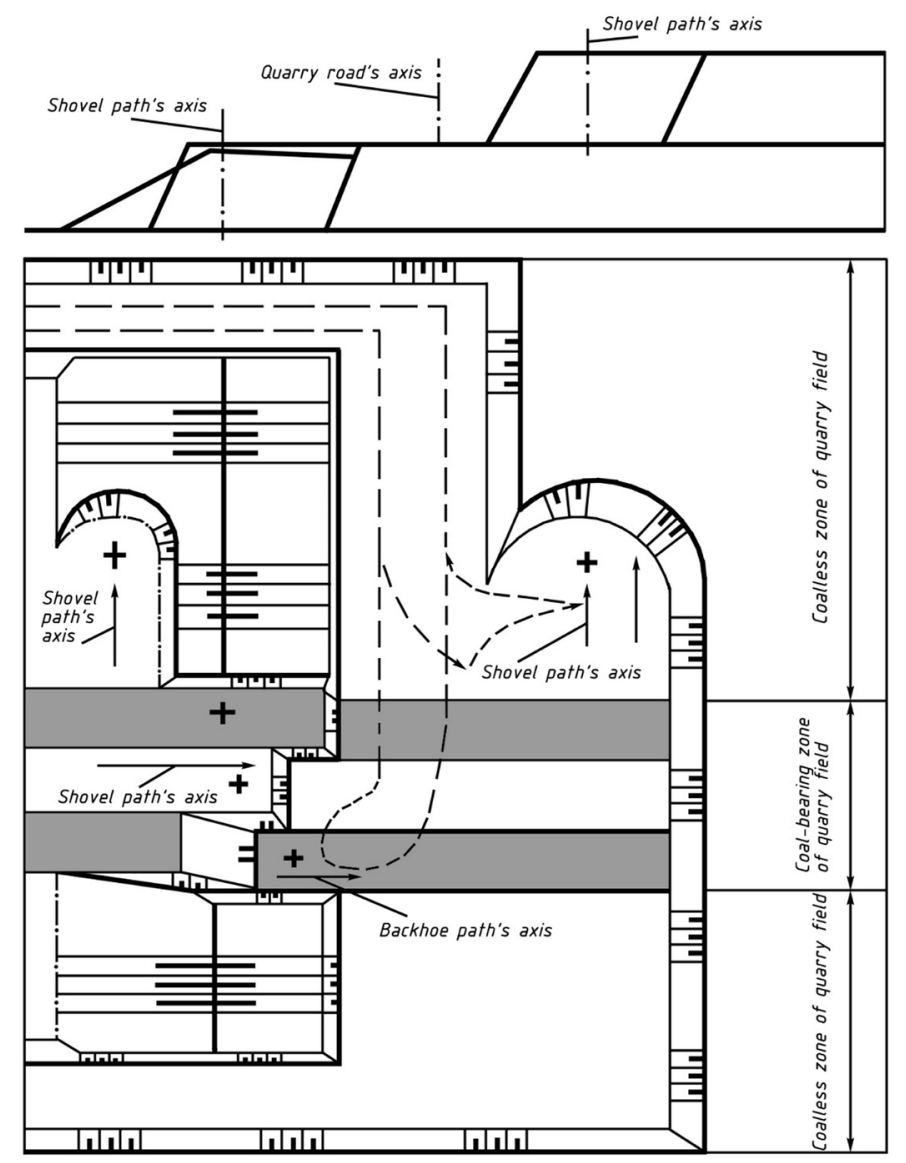

Fig. 1. Principal scheme of mining of the coal-bearing and coalless zone of the quarry field by set of rope (or hydraulic) shovels and backhoes.

In order to meet the requirements to the technology mentioned above, the following organization of work is proposed for coal seams development. The excavator can be installed both on the roof of the bench, and if the thickness of the rock partings allows, and on the bottom of the bench. Loading of coal and rocks - on the ground level or above it. Initially, excavation of the seam or a group of close seams, the coal grade of which is necessary for a given period of time, is performed, with longitudinal motion of the mining front.

The coal is transported to a coal storage or technical complex for processing. After all the coal seams are excavated, a solid rock mass (i.e. coalless zone) is formed within the 
excavation layer. Then, when the mining front is moved crosswise, the rock partings and the coalless zone are mined off. The overburden zone can be stripped out with powerful high-capacity stripping equipment.

Advantages of the technology are:

- continuous stripping front is created, which can be stripped out with a powerful highperformance equipment;

- stability of the branded coal composition over a certain period of time (for example, daily production);

- mining front direction changes only within a short time;

- angle at which the coal seam meets the excavator stope is not important;

- organization of works is simplifying.

\section{Conclusion}

Joint study of requirements to the technology of development of coal-and-rock massif and sources of scientific and technical literature shows that there is a clear separation of the joint use of excavation complexes based on excavators such as rope shovels and backhoes with the combined development of coal-bearing and coalless zones of the quarry field.

It is established that in some papers the preconditions for the layer mining of coal seams are given according to the criteria mutually linking the location of the seams relative to each other in the excavation layer and the parameters of their excavation by backhoes, but not providing for the layer mining of rock partings and coalless zone by stripping excavators (rope shovels).

The proposed technology of transformation the coal-bearing zone into a coalless one by means of outpacing coal seam excavation is very promising for the mining of inclined and steep seams, especially in complex-structured coal deposits.

\section{References}

1. S. Frimpong, Y. Hu, K. Awuah-Offei, J of Terramechanics, 15 (2005)

2. P. P. Bhaveshkumar, J. M. Prajapati, Int J of Mechanisms and Robotic Systems, 1:4, $261(2013)$

3. B. Scott, P. G. Ranjith, S.K. Choi, K. Manoj, J Min Sci, 46, 280 (2010)

4. V. F. Kolesnikov, M. Cehlár, E. A. Tyuleneva, Journal of Mining and Geotechnical Engineering, 2, 36 (2018) DOI: 10.26730/2618-7434-2018-2-36-49

5. R. A. Conigliaro, A. A. Kerzhner, C. J. J. Paredis, C.J.J. (2009), SAE Int J of Materials and Manufacturing, 1, 0565 (2009) https://doi.org/10.4271/2009-01-0565

6. A. V. Katsubin, A. A. Fedotov, Journal of Mining and Geotechnical Engineering, 3, 60 (2019) DOI: 10.26730/2618-7434-2019-3-60-75

7. E. A. Tyuleneva, Yu. V. Lesin, Ya. O. Litvin, Journal of Mining and Geotechnical Engineering, 1, 35 (2019) DOI: 10.26730/2618-7434-2019-1-35-49

8. R. Moore, C. J. J. Paredis, Proc of ASME 2009 Int Design Eng Tech Conf, 79 (2010) https://doi.org/10.1115/DETC2009-87522

9. J. R. Zhang, A. L. Wang, S. T. Song, D. M. Cui, Journal of North University of China (Natural Science Edition), 2, 007 (2011)

10. A. V. Strelnikov, Journal of Mining and Geotechnical Engineering, 3, 4 (2019) DOI: $10.26730 / 2618-7434-2019-3-4-20$ 
11. B. X. Nam, C. Drebenstedt, Innovative Entwicklung und Konzepte in der Tagebautechnik, 175 (2009)

12. A. V. Strelnikov, Journal of Mining and Geotechnical Engineering, 4, 4 (2019) DOI: 10.26730/2618-7434-2019-4-4-29

13. V. V. Rzhevskiy, Open pit mining, part 1 (Nedra, Moscow, 1985)

14. V. V. Rzhevskiy, Open pit mining, part 2 (Nedra, Moscow, 1985) 